Cite this article as: El Hanandeh, A. (2015). Environmental assessment of popular single-family house construction alternatives in Jordan. Building and Environment, 92, pp192-199.

\title{
Environmental assessment of popular single-family house construction alternatives in Jordan
}

\author{
Ali El Hanandeh \\ Environmental Futures Research Institute, School of Engineering, Griffith University Nathan QLD \\ 4111 Australia
}

Email: a.elhanandeh@griffith.edu.au

Tel: +61 737356635 (office)

\begin{abstract}
The building and construction sector is vital in Jordan. Over the past decade it witnessed rapid growth. Single-family housing is a popular option in Jordan. The construction sector consumes large amounts of energy and resources. Green and energy efficient buildings are growing in popularity and there are policies adopted to encourage energy efficient buildings. These buildings are often justified based on energy saving during the operation phase. Nevertheless, up to date, there is no study that analyses the efficiency of these buildings in Jordan from a life cycle perspective. In this study, the six most popular construction configurations for a single family house in Jordan are assessed using "cradle to grave" life cycle methodology. The alternatives included: single hollow concrete block (Economic), double layer hollow concrete blocks (improved economic), double layer hollow concrete blocks with insulation layer (insulated economic), typical limestone cladding, insulated limestone wall and multi-layer with limestone cladding and insulation (luxury). The results show that using the typical Jordanian family thermal comfort level and heating and cooling patterns, the economic house is the option that performs best in terms of energy resources (5050 UBP), climate change ( $727.85 \mathrm{Mg} \mathrm{CO}_{2 \text { eq }}$ ), acidification ( $2.91 \mathrm{Mg} \mathrm{SO}_{2 \text { eq }}$ ) and particulate matter formation (1.14 $\mathrm{Mg} \mathrm{PM}_{10}$ eq). Limestone cladded houses show better results in terms of human toxicity and water depletion impact. The results further suggest that energy resource and water depletion impacts may be used as proxy indicators for the overall performance of the building.
\end{abstract}

Key words: LCA; single family house; exterior wall; energy efficient buildings; stone wall 
Cite this article as: El Hanandeh, A. (2015). Environmental assessment of popular single-family house construction alternatives in Jordan. Building and Environment, 92, pp192-199.

\section{Introduction}

The building and construction sector is a rapidly growing economic sector in Jordan. The sector is expected to expand at a rate of $20 \%$ over the next five years with the residential sector contributing $75 \%$ of the growth due to natural population growth and migration [1]. Building and construction is a material intensive activity that accounts for $40 \%$ of the world material and energy flows [2]. Jordan is a small country with limited resources. It imports $97 \%$ of its energy needs. Furthermore, Jordan is one of the most water-scarce countries in the world [3].

Efficient use of available resources and reduction of waste in residential buildings can contribute significantly to the sustainability of the sector. Over the last two decades, the building and construction sector in Jordan has seen a dramatic shift away from traditional construction methods and materials towards modern construction technology. Nevertheless, green buildings design has witnessed renewed interest in recent years. For example, guidelines and regulations to reduce energy consumption during the operational period of the building are developed. In many cases, these guidelines do not take into account energy use during the full life cycle of the building [4]; neither do they consider other potential environmental impacts such as water use, acidification and human health. Life cycle assessment (LCA) is a standardised methodology which offers comprehensive assessment of the environmental performance of a building throughout its life cycle.

Based on LCA results, Adalberth [5] concluded that $85 \%$ of the energy consumed throughout the life cycle of a building is attributed to the use (operational) phase. A literature review concluded that 62 $98 \%$ of the environmental impacts of a building may be attributed to the operational phase [6]. However, Monteiro and Freire [4] noted that while many LCA studies tend to confirm Adalberth's conclusion, most of the studies were conducted in cold climate regions. Nevertheless, Radhi and Sharples [7] found that $80-90 \%$ of the environmental impacts of a building may be attributed to the operational phase after conducting a LCA study on residential buildings in Bahrain. The high impacts during the operation phase can be attributed to high energy use. In fact, when considering the Portuguese reduced HVAC levels, material production is the process which is responsible for the most environmental impacts of a single-family house [4].

The design of the building façade and exterior walls play an important role in the thermal performance and lighting conditions of the building $[6,8]$. In turn, exterior wall construction affects the energy consumption during the use phase of the building. Therefore, it is not surprising that current practices in Jordan focus on exterior wall construction and windows to alter the energy requirements of the house; with the aim to reduce the heating and cooling demand. The Jordanian energy efficient building code recommends thermal transfer values for various components of the building [9]. These values were derived from simulating the thermal comfort levels for an active and passive model apartment in Amman during the operation phase of the building [10]. Ali and Nsairat [11] developed SABA as a tool to evaluate green buildings in Jordan. It uses AHP multi-criteria evaluation to assign a score based on developed criteria which includes site, material, cost, water and energy efficiency as well as indoor air quality. However, no LCA study of the housing sector in Jordan was conducted. Jordan has comparable climate conditions and HVAC levels to Portugal. 
Cite this article as: El Hanandeh, A. (2015). Environmental assessment of popular single-family house construction alternatives in Jordan. Building and Environment, 92, pp192-199.

doi:10.1016/j.buildenv.2015.04.032

Excessive use of material may be counter effective if the energy savings during the operation phase are not sufficient to offset the impacts incurred due to the extra use of material.

Irbid is the governorate with the highest population density in Jordan and the second largest in terms of population numbers after the capital Amman [12]. According to official statistics, Irbid had 164,733 housing units as of 2004. Nearly one third of which are classified as single-family housing [13]. However, the housing sector in Irbid has seen dramatic growth over the past few years due to natural population increase and migration from neighbouring countries as a result of political instability in the region.

To the best of the author's knowledge, there has been no study conducted to assess the overall environmental impacts of a single-family home construction in Jordan. In this study, LCA is used to evaluate and compare the efficiency of the most common methods for the construction of external walls of a single family home in Irbid, Jordan. Although, this study uses a single-family house in Irbid in the analysis, the results are relevant to the other parts of Jordan as well as other countries in the region as the climate conditions, construction methods, cultural and operation of buildings are similar.

\section{Methods}

Life cycle assessment (LCA) is a standardised method (ISO 14040:2006). It consists of Four phases: Scope and goal definition; life cycle inventory (LCI); life cycle impact assessment (LCIA); and interpretation [14]. The modelling was carried out in openLCA v1.4 [15]. The Life cycle inventory (LCI) was collected from published literature. The ReCiPe Midpoint (H) LCIA method was used to assess the environmental impacts.

\subsection{Goal and Scope Definition}

The goal of this study is to evaluate the environmental impacts of a single-family house in Jordan over its life time assuming typical HVAC levels of a Jordanian family-house. The aim is to evaluate the efficiency of different exterior wall construction on the overall environmental performance of the house throughout its life span. The life span of a house depends on many factors. Nevertheless, several LCA studies used 50 years as the practical life span of a house $[4,16]$. This study is directed towards architects, engineers and policy makers who are directly involved in the design and construction of buildings in Jordan.

\subsection{System boundary and functional unit}

The study uses an example three bedroom single-family house with a floor area of $144 \mathrm{~m}^{2}$ (Figure 1) located in Irbid, Jordan to analyse material and energy requirements. The study follows LCA 'cradle to grave' methodology. It covers the material, construction, use, demolition and disposal stages of a single-family house.

The system definition includes material production, acquisition, transportation to construction site, installation, operation phase, maintenance and demolition and disposal. The functional unit chosen for this study is the whole unit as shown in Figure 1 over the entire life span of the building. 
Cite this article as: El Hanandeh, A. (2015). Environmental assessment of popular single-family house construction alternatives in Jordan. Building and Environment, 92, pp192-199.

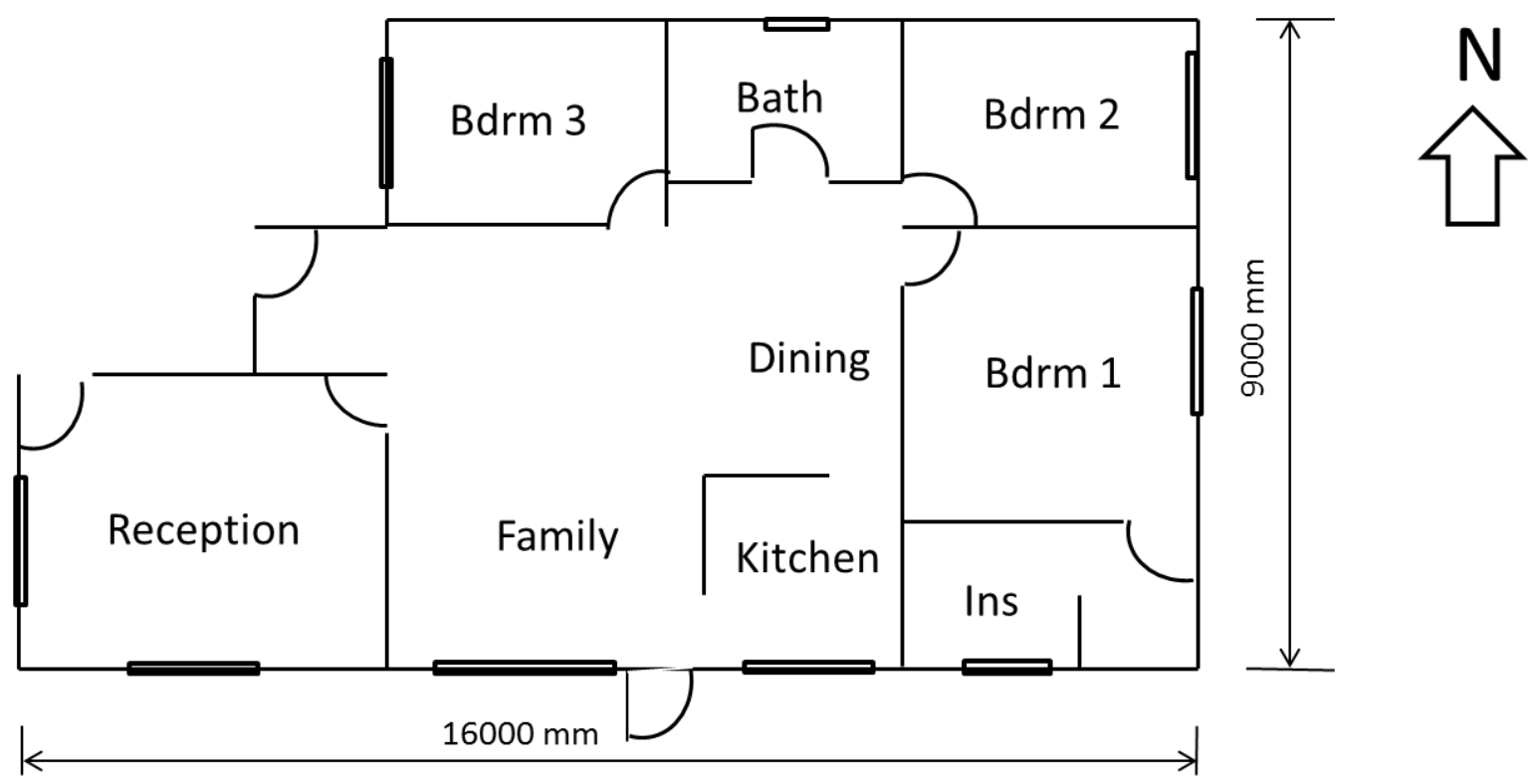

Figure 1 Floor plan of modelled house/apartment

\subsection{System description and life cycle inventory}

Material and energy consumption throughout the life span of the building, shown in Figure 1, are calculated based on the six most common exterior wall construction configurations in Jordan. Heating and cooling requirements are calculated using the Jordanian common HVAC levels rather than the entire house. Window areas are calculated based on the Jordan energy efficient buildings code [9].

Exterior wall construction: six (6) exterior wall configurations that are most common in the Jordan housing market are considered in this study: economical; improved economical; insulated; limestone façade; insulated limestone façade and luxurious exterior wall. Walls in Jordan are typically nonload bearing. The load is usually carried by frame constructed on site using reinforced concrete columns and beams. Therefore, exterior walls are usually non-structural elements of the house and can be altered easily without affecting the structural integrity of the building. Furthermore, as exterior walls are non-structural elements, the need for allocation of impacts is eliminated.

Economical exterior wall configuration, wall type $a$, (Figure 2- a) was widely used in the older building stock in Jordan. It is still a popular wall configuration for a single-family house and multiunit flats of the lower middle economic class. It typically consists of a single layer of $150 \mathrm{~mm}$ hollow concrete blocks with $25 \mathrm{~mm}$ cement plaster on both sides. Cement mortar with a typical joint thickness of $10 \mathrm{~mm}$ is used to fix blocks in place.

In the Improved economical exterior wall, wall type $b$, the configuration is the most commonly used configuration of the economic single-family house and multi-unit flats. It typically consists of two layers of hollow concrete blocks with a $50 \mathrm{~mm}$ gap. The wall is cladded on both sides with $25 \mathrm{~mm}$ cement plaster as shown in Figure 2-b. 
Cite this article as: El Hanandeh, A. (2015). Environmental assessment of popular single-family house construction alternatives in Jordan. Building and Environment, 92, pp192-199.

Insulated wall, wall type $c$, is the same as the improved economical configuration with the replacement of the gap with expanded or extruded polystyrene insulation (Figure 2-c). This is the recommended wall configuration by the Jordan building code.

Limestone façade, wall type $d$, is very common among the economic middle and upper middle-class single-family houses, flats and high-standard units. Limestone façade is also required for all walls facing roads for buildings in commercial zones. In Jordan, limestone is used as cladding and usually does not serve structural function. A typical limestone façade consists of a limestone cladding $30-$ $50 \mathrm{~mm}$ thickness backed by $100 \mathrm{~mm}$ concrete wall followed by $100 \mathrm{~mm}$ hollow concrete blocks and $25 \mathrm{~mm}$ cement plaster (Figure 2- d).

Insulated limestone exterior walls, wall type $e$, are similar to the typical limestone configuration with the exception of insulation installed between the concrete and hollow block layer (Figure 2- e).

The last exterior wall configuration, wall type $f$, considered in this study is the luxurious exterior wall design. This is common in upper-middle and upper economic class single-family houses and villas. The wall configuration consists of $30-50 \mathrm{~mm}$ limestone façade backed by $100 \mathrm{~mm}$ concrete wall followed by $100 \mathrm{~mm}$ hollow concrete block followed by $50 \mathrm{~mm}$ insulation then $100 \mathrm{~mm}$ hollow concrete block and finally a $25 \mathrm{~mm}$ of cement plaster (Figure 2-f). This multi-layer configuration is perceived to offer excellent thermal comfort. Table 1 presents a summary of the quantities for each wall configuration including $10 \%$ wastage allowance. In all cases, interior (dividing walls) are usually made of $100 \mathrm{~mm}$ thick hollow concrete blocks with $25 \mathrm{~mm}$ cement plaster on both sides.

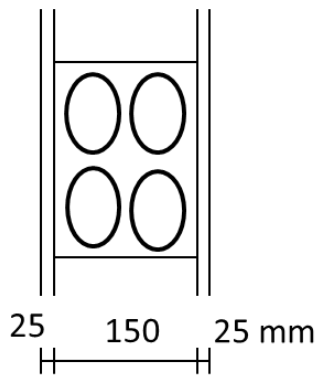

(a)

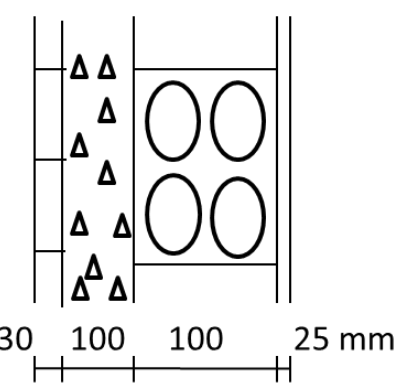

(d)

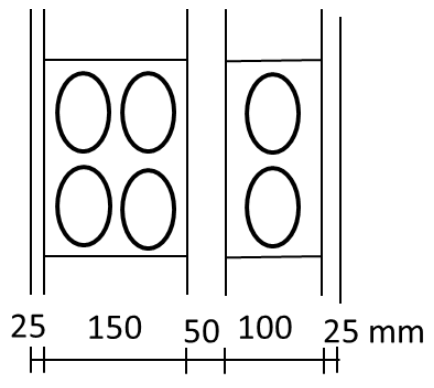

(b)

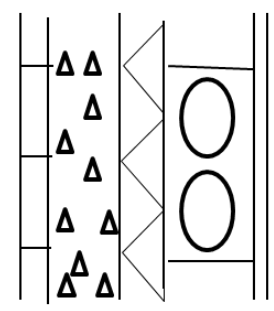

$30 \quad 100 \quad 50 \quad 10025 \mathrm{~mm}$

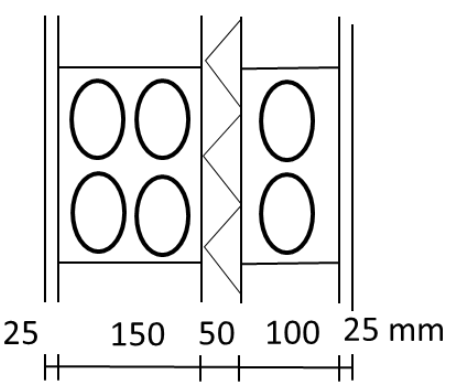

(c)

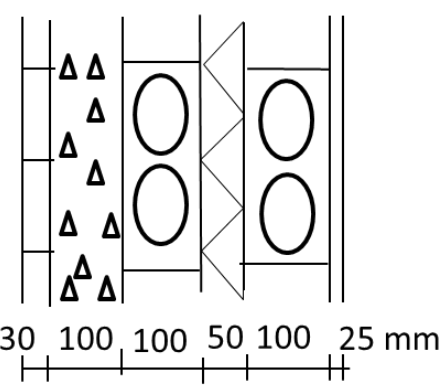

(e) 
Cite this article as: El Hanandeh, A. (2015). Environmental assessment of popular single-family house construction alternatives in Jordan. Building and Environment, 92, pp192-199.

Figure 2. Exterior wall cross sections (not to scale).

Windows

Single glazed windows with aluminium frame are the most common type installed in economic houses. Double glazed windows are usually installed in high-standard houses. Although other types of frames such as PVC and wood are available, they are not popular in Jordan. In this study, single glazed windows are assumed to be installed with wall sections $a-d$ and double glazed windows are assumed to be installed with wall sections $e$ and $f$. Windows are commonly installed 120-150 mm recessed in the wall.

Table 1. Bill of material for different wall construction including interior walls

\begin{tabular}{|c|c|c|c|c|c|c|}
\hline \multirow[t]{2}{*}{ Material } & \multicolumn{6}{|c|}{ Wall construction type } \\
\hline & Economical & $\begin{array}{l}\text { Improved } \\
\text { Econ. }\end{array}$ & $\begin{array}{l}\text { Insulated } \\
\text { Improved } \\
\text { Econ. }\end{array}$ & $\begin{array}{l}\text { Typical } \\
\text { Limestone }\end{array}$ & $\begin{array}{l}\text { Insulated } \\
\text { Limestone }\end{array}$ & Luxurious \\
\hline $\begin{array}{l}\text { Concrete } \\
\text { hollow blocks } \\
\text { (150 mm } \\
\text { thickness - } \\
\text { units) }\end{array}$ & 2050 & 2050 & 2050 & - & - & - \\
\hline $\begin{array}{l}\text { Concrete } \\
\text { hollow blocks } \\
\text { (100 mm } \\
\text { thickness - } \\
\text { units) }\end{array}$ & 470 & 2520 & 2520 & 2520 & 2520 & 4570 \\
\hline $\begin{array}{l}\text { Limestone cut } \\
30 \mathrm{~mm} \\
\text { thickness }\left(\mathrm{m}^{2}\right)\end{array}$ & - & - & - & 440 & 440 & 440 \\
\hline $\begin{array}{l}\text { Cement plaster } \\
\left(\mathrm{m}^{3}\right)\end{array}$ & 6.2 & 6.2 & 6.2 & 3.1 & 3.1 & 3.1 \\
\hline $\begin{array}{l}\text { Expanded } \\
\text { Polystyrene } \\
\left(\mathrm{m}^{2}\right)\end{array}$ & - & - & 123 & - & 123 & 123 \\
\hline $\begin{array}{l}\text { Cement Mortar } \\
\left(\mathrm{m}^{3}\right)\end{array}$ & 2.2 & 3.2 & 3.2 & 1.68 & 1.68 & 2.73 \\
\hline Concrete $\left(\mathrm{m}^{3}\right)$ & - & - & - & 12.5 & 12.5 & 12.5 \\
\hline $\begin{array}{l}\text { Glass - } 4 \mathrm{~mm} \\
\left(\mathrm{~m}^{2}\right)\end{array}$ & 16.2 & 16.2 & 16.2 & 16.2 & 32.4 & 32.4 \\
\hline $\begin{array}{l}\text { Aluminium } \\
\text { window frame } \\
(\mathrm{kg})\end{array}$ & 72 & 72 & 72 & 72 & 108 & 108 \\
\hline
\end{tabular}

Roof

Houses in Jordan usually have a flat roof made of cast in situ reinforced concrete. The roof is supported by a concrete frame made of a system of beams carried by reinforced concrete columns. 
Cite this article as: El Hanandeh, A. (2015). Environmental assessment of popular single-family house construction alternatives in Jordan. Building and Environment, 92, pp192-199.

Another system of beams connecting the columns is usually constructed at ground level to support the walls. A typical roof configuration is shown in Figure 3. In a Luxury house it is assumed that it will have a layer of asphalt for water proofing and a layer of gravel on top of the typical roof shown in Figure 3.

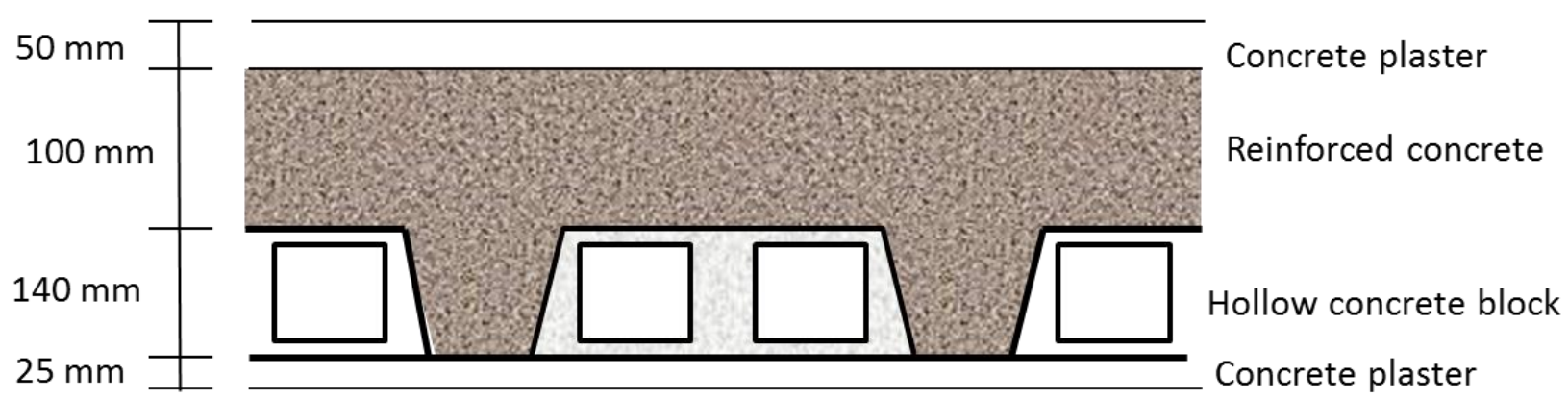

Figure 3: Cross section in a typical flat roof in Jordan (not to scale).

Foundations

Footings are the most common foundation type used for single family house in Jordan. Footings are usually cast in situ using pre-prepared concrete mix.

Table 2 presents a summary of material used in the construction of the roof, frame and foundation.

Table 2: Bill of material for the construction of the frame and roof

\begin{tabular}{|c|c|c|c|c|c|c|}
\hline \multirow[t]{2}{*}{ Element } & \multicolumn{6}{|l|}{ Type } \\
\hline & Economical & $\begin{array}{l}\text { Improved } \\
\text { Economical }\end{array}$ & $\begin{array}{l}\text { Insulated } \\
\text { Improved } \\
\text { Economical }\end{array}$ & Limestone & $\begin{array}{l}\text { Insulated } \\
\text { limestone }\end{array}$ & Luxurious \\
\hline \multicolumn{7}{|c|}{ Concrete $\left(\mathrm{m}^{3}\right)$} \\
\hline Roof & 13.5 & 13.5 & 13.5 & 13.5 & 13.5 & 13.5 \\
\hline $\begin{array}{l}\text { Floor Slab \& } \\
\text { connector } \\
\text { beams }\end{array}$ & 5.9 & 10.3 & 10.3 & 10.3 & 14.4 & 20.3 \\
\hline Footings & 12 & 12 & 12 & 12 & 12 & 12 \\
\hline Columns & 3.6 & 3.6 & 3.6 & 3.6 & 3.6 & 3.6 \\
\hline Beams & 8.6 & 8.6 & 8.6 & 8.6 & 8.6 & 8.6 \\
\hline Total & 43.6 & 48 & 48 & 48 & 52.1 & 58 \\
\hline Cement Plaster $\left(\mathrm{m}^{3}\right)$ & 3.6 & 3.6 & 3.6 & 3.6 & 3.6 & 3.6 \\
\hline Bitumen $\left(\mathrm{m}^{3}\right)$ & - & - & - & - & - & 3.6 \\
\hline Gravel $\left(\mathrm{m}^{3}\right)$ & - & - & - & - & - & 4.3 \\
\hline $\begin{array}{l}\text { Concrete hollow } \\
\text { blocks - roof (MCU) }\end{array}$ & 1980 & 1980 & 1980 & 1980 & 1980 & 1980 \\
\hline \multicolumn{7}{|c|}{ Reinforcement Steel (Mg) } \\
\hline Roof & 1.1 & 1.1 & 1.1 & 1.1 & 1.1 & 1.1 \\
\hline Floor Slab \& & 0.71 & 0.94 & 0.94 & 0.94 & 1.14 & 1.85 \\
\hline
\end{tabular}


Cite this article as: El Hanandeh, A. (2015). Environmental assessment of popular single-family house construction alternatives in Jordan. Building and Environment, 92, pp192-199.

\begin{tabular}{l|llllll}
$\begin{array}{l}\text { connector } \\
\text { beams }\end{array}$ & \multicolumn{7}{|c}{} & & & & \\
Footings & 1.26 & 1.26 & 1.26 & 1.26 & 1.26 & 1.26 \\
Columns & 0.55 & 0.55 & 0.55 & 0.55 & 0.55 & 0.55 \\
Beams & 1.1 & 1.1 & 1.1 & 1.1 & 1.1 & 1.1 \\
\hline Total & 4.72 & 4.95 & 4.95 & 4.95 & 5.15 & 5.86 \\
\hline
\end{tabular}

Material procurement

Jordan manufactures almost all types of construction material including gravel, cement, steel reinforcement bars, aluminium profiles and limestone [9]. It is therefore, assumed that locally produced materials are used in the construction. Sand and gravel are assumed to be purchased from one of the many local quarries and crushing factories available within $40 \mathrm{~km}$ from the site. Concrete blocks are also assumed to be purchased from one of the many small block factories within $40 \mathrm{~km}$ from the site. Steel bars are transported from the steel factory in Al Zarka about $70 \mathrm{~km}$. Cement is assumed to be purchased from the local factory in Qatrana located $170 \mathrm{~km}$ south of Irbid and limestone is brought from the local quarries about $40 \mathrm{~km}$ from the site. Data for quarrying and processing of limestone was adapted from the UT Center for Clean products [17]. LCl data for concrete and masonry concrete units are adapted from Medgar et al. [18]. LCl data for steel rebar is sourced from ELCD database 2.0 [19]. All data were adapted to represent Jordanian transportation, energy mix and production methods.

House demolition and material disposal

Houses are usually stripped of valuable material that can be easily recycled, such as aluminium windows and frames which then are sold as scrap metal. The rest of the material from demolition is landfilled. In Jordan, it is uncommon to recycle concrete from dismantling of buildings into aggregates or reinforcement steel bars as they are difficult to extract from the rubble. In this study, only aluminium windows and frames are assumed recyclable. All other material is assumed to be sent to the landfill.

\subsection{Heating and cooling}

Typical single family houses in Jordan are designed as active houses. Therefore, heating during winter and cooling during summer is needed. Irbid has a mild Mediterranean climate with rainy winters and dry summers. Average monthly temperatures are shown in Table 3. Most studies about HVAC assume that the entire house is heated or cooled to a desired temperature all the time $\left(20^{\circ} \mathrm{C}\right.$ in winter and $25^{\circ} \mathrm{C}$ in summer). This is not the case in a typical Jordanian house. In most cases, a single room (family/living) is heated while occupants are in the house. Other rooms, for example bedrooms, are usually not heated or heated for short periods during the night. A similar scenario is also followed for cooling. Most houses use electric fans as the main cooling device in summer. This is possible due to the low humidity levels during summer. In this study, we calculate the HVAC requirements using typical Jordanian house heating and cooling patterns. None-flued LPG heaters 
Cite this article as: El Hanandeh, A. (2015). Environmental assessment of popular single-family house construction alternatives in Jordan. Building and Environment, 92, pp192-199.

are most commonly used for space heating in the house [10]. This study assumes that the family/living room is heated for three hours during the daytime and six hours during the night. All bedrooms are heated for three hours during night time only. An average Jordanian family size of 5.1 people is assumed [20]. Table 4 presents a summary of U-values (thermal transmission) for the wall configurations described earlier. All interior (dividing) walls are assumed to be the same and have a $\mathrm{U}$-value of $2.08 \mathrm{~W} / \mathrm{K} \cdot \mathrm{m}^{2}$.hr. U-values are the inverse values of thermal resistance of the wall (R). $R$ value of a wall is calculated as the summation of the $R$ values for each component of the wall.

Table 3. Average monthly temperatures and daily sunlight hours in Irbid, Jordan, source [21].

\begin{tabular}{l|lll}
\hline Month & $\begin{array}{l}\text { Average } \\
\text { High }{ }^{\circ} \mathrm{C}\end{array}$ & $\begin{array}{l}\text { Average } \\
\text { Low }{ }^{\circ} \mathrm{C}\end{array}$ & $\begin{array}{l}\text { sunlight } \\
\text { hours }\end{array}$ \\
\hline January & 13 & 4 & 5 \\
February & 14 & 5 & 6 \\
March & 17 & 7 & 7 \\
April & 21 & 10 & 8 \\
May & 26 & 14 & 10 \\
June & 29 & 17 & 12 \\
July & 31 & 19 & 11.5 \\
August & 31 & 19 & 11 \\
September & 29 & 18 & 10 \\
October & 26 & 15 & 8.5 \\
November & 20 & 10 & 7 \\
December & 15 & 6 & 5 \\
\hline
\end{tabular}

Table 4. $U$ values for wall and other elements (W/K.m $\left.\mathrm{m}^{2} . \mathrm{hr}\right)$

\begin{tabular}{l|llll}
\hline $\begin{array}{l}\text { Exterior wall } \\
\text { configuration }\end{array}$ & U-Exterior Wall & U-Window & U-Door & U-Ceiling \\
\hline Economic & 2.38 & 6.27 & 2.62 & 2.02 \\
Improved Economic & 1.38 & 6.27 & 2.62 & 2.02 \\
Insulated Economic & 0.70 & 6.27 & 2.62 & 2.02 \\
Limestone & 1.71 & 6.27 & 2.62 & 2.02 \\
Insulated limestone & 0.77 & 3.37 & 2.62 & 2.02 \\
Luxurious & 0.70 & 3.37 & 2.62 & 1.80 \\
\hline
\end{tabular}

\subsection{Internal and solar gain}

Human occupants and electronic/electrical devices emit energy into the surrounding space. In this study, it is assumed that during the day only three (almost half) of the occupants are in the house. The amount of heat emitted depends on the level of activity, the type of lighting and electrical equipment in the room. However, for the sake of simplicity, it is assumed that the internal gain is 4 $\mathrm{W} / \mathrm{m}^{2}[4]$. 
Cite this article as: El Hanandeh, A. (2015). Environmental assessment of popular single-family house construction alternatives in Jordan. Building and Environment, 92, pp192-199.

Jordan is a sun soaked country, on average there more than 300 sunny days per year with an average global radiation of $2080 \mathrm{kWh} / \mathrm{m}^{2}$ [22]. Therefore, heat gain from solar radiation plays an important role in determining the HVAC requirements of buildings. In this case, the long side of the house is oriented to face south according to the green buildings code [9]. Solar gain factors for Irbid are presented in Table 5.

Table 5. Solar gain on vertical surfaces in Irbid, adapted from [23].

\begin{tabular}{lcccccccccccc}
\hline & Jan & Feb & Mar & Apr & May & Jun & Jul & Aug & Sep & Oct & Nov & Dec \\
\hline \multicolumn{10}{c}{} & \multicolumn{10}{c}{ Single Pane Clear Glass $\left(\mathrm{kWh} / \mathrm{m}^{2}\right.$. day $)$} \\
\hline South & 3.26 & 3.16 & 2.67 & 1.88 & 1.36 & 1.19 & 1.25 & 1.68 & 2.61 & 3.53 & 3.69 & 3.36 \\
East & 1.10 & 1.64 & 2.03 & 2.56 & 2.88 & 3.01 & 2.17 & 2.09 & 2.45 & 1.93 & 1.31 & 1.03 \\
West & 1.10 & 1.64 & 2.03 & 2.56 & 2.88 & 3.01 & 2.17 & 2.09 & 2.45 & 1.93 & 1.31 & 1.03 \\
North & 0.55 & 0.69 & 0.87 & 1.05 & 1.19 & 1.30 & 1.26 & 1.10 & 0.93 & 0.74 & 0.57 & 0.51 \\
\hline \multicolumn{10}{c}{ Double Pane Clear Glass $\left(\mathrm{kWh} / \mathrm{m}^{2}\right.$. day) } \\
\hline South & 2.81 & 2.68 & 2.23 & 1.53 & 1.10 & 1.00 & 1.03 & 1.35 & 2.17 & 3.00 & 3.20 & 2.90 \\
East & 0.97 & 1.29 & 1.71 & 2.20 & 2.45 & 2.57 & 2.61 & 2.65 & 2.10 & 1.65 & 1.77 & 0.87 \\
West & 0.97 & 1.29 & 1.71 & 2.20 & 2.45 & 2.57 & 2.61 & 2.65 & 2.10 & 1.65 & 1.77 & 0.87 \\
North & 0.45 & 0.61 & 0.74 & 0.87 & 1.00 & 1.10 & 1.06 & 0.94 & 0.77 & 0.65 & 0.50 & 0.45 \\
\hline
\end{tabular}

Another factor that affects the HVAC requirements is the air change rate (ach). In this study, it is assumed that for the economical, improved economical and limestone house air changes once every hour (ach=1). In the case of insulated improved economical and insulated limestone an ach of 0.6 is assumed while an ach of 0.5 is assumed for the case of luxurious design. Lower ach rates for higher quality houses are assumed to reflect the better quality seals and workmanship.

\subsection{Life cycle impact assessment}

Life cycle impact assessment (LCIA) methods can be categorised according to the impacts they model; being either single or multi-category. Multi-category LCIA methods can be further classified into two classes: midpoint or endpoint methods. Midpoint methods are problem oriented and offer higher transparency because they model the impacts at an early stage of the cause-effect chain. On the other hand, endpoint methods are usually damage oriented as they tend to model the consequences of impacts up the chain to the possible damage to humans or ecosystems. As a result, endpoint methods entail higher levels of uncertainty [4].

In this study, ReCiPe Midpoint (H) LCIA method [24] is used to categorise and assess the environmental impacts of each option. The following impact categories are deemed relevant in Jordanian context: Water Depletion; Climate Change; Acidification; Human Toxicity and Particulate Matter formation. Total energy Resource is assessed using the Ecological Scarcity Method 2006 [25]. The environmental mechanisms used to translate the emissions to impact values are beyond the scope of this study. For more information about the environmental mechanisms used by ReCiPe and Ecological Scarcity methods, the reader may consult the manual of the concerned LCIA method $[24,25]$. 
Cite this article as: El Hanandeh, A. (2015). Environmental assessment of popular single-family house construction alternatives in Jordan. Building and Environment, 92, pp192-199.

doi:10.1016/j.buildenv.2015.04.032

Water depletion is deemed important as Jordan is one of the driest countries in the world. The country faces a severe water scarcity situation. According to the official figures, annual water resources are less than $145 \mathrm{~m}^{3}$ per capita [26]. Countries with annual water resources less than 1000 $\mathrm{m}^{3}$ per capita are classified as water resource poor. The Jordanian government has ratified the Kyoto protocol as a non-Annex-I country and has issued an official national climate change policy which commits to reducing greenhouse gas emissions [27]. Therefore, climate change impact is considered in this study. Jordan is rich with archaeological sites, many of which are surrounded by or in close proximity to residential areas. Archaeological sites are vulnerable to acid rain and acidification, therefore, acidification impact is deemed important in this study. Human toxicity and particulate matter are assessed as indicators of the potential health impacts on humans. Energy consumption is an important factor in Jordan as the country imports $97 \%$ of its energy needs [28]. Furthermore, extra use of material in buildings is often justified by the amount of energy saving from HVAC. Therefore, total energy resource consumption by each alternative is assessed using the ecological scarcity method 2006.

Smog events are extremely rare in Jordan. Therefore, photochemical oxidant formation is deemed irrelevant in this study. Desert covers the vast majority of Jordanian land. Furthermore, Jordan has little to negligible surface water bodies and the land is highly degraded due to desertification, salinization and excessive urbanisation. As a result, eutrophication is considered irrelevant in the Jordanian context. Ozone depletion is mainly a southern hemisphere issue. Hence, it is ignored in this study.

\section{Results and Discussion}

Space heating requirements and energy saving for the six building configurations during the operation phase of the building life cycle are presented in Table 6. As shown in table 6, the economic house configuration is the least efficient while the luxury house is the most efficient in terms of home heating energy requirements. The extra insulation, provided by the wall and ceiling configurations, performs as intended by reducing the operational energy requirements. In fact, the luxury house requires less than half (44\%) of the energy required by the economical house to maintain an assumed thermal comfort level of $20^{\circ} \mathrm{C}$ inside the living space during winter. Although, the results are in agreement with the commonly held perception, it only marginally outperforms the insulated economic house and insulated limestone house with savings of $8 \%$ and $11 \%$, respectively. In terms of greenhouse gas emissions, over the operational life span of the house, the luxury house presents a reduction of more than $30 \mathrm{Mg} \mathrm{CO}_{2}$ due to reduced LPG combustion. However, as evident from Table 7, these savings are not sufficient to offset the life cycle energy and greenhouse gas emissions incurred due to the intensive material requirements of the luxury house. In fact, the economic house presents the best results when it comes to life cycle energy resource consumption, particulate matter, greenhouse gas emissions and acidification impact. The typical limestone house is the best performer in human toxicity and water depletion categories, it also ranks second in climate change, particulate matter formation, acidification and energy resources categories despite the fact that it offers the least savings in space heating energy requirements (127 GJ) when compared to other options. These results are not surprising given the low demand for space heating and the customary heating pattern by Jordanian families. The findings of this study support findings 
Cite this article as: El Hanandeh, A. (2015). Environmental assessment of popular single-family house construction alternatives in Jordan. Building and Environment, 92, pp192-199.

by Monteiro and Freire [4] who reported that space heating accounted to $10 \%$ of Portuguese singlefamily houses over the life span of the house under typical thermal comfort conditions of Portuguese families.

In this study it is assumed that the temperature inside the room is constant. However, Barrios et al $[29,30]$ demonstrated, using one dimensional thermal transfer modelling, the importance of taking into account the time dependency factor when assessing the thermal performance of airconditioned and non-air-conditioned rooms, especially in areas that receive significant solar radiation. Barrios et al [29] concluded that the most important parameter for air-conditioned rooms is the thermal conductivity of the wall while thermal diffusivity is the most important physical property in the case of non-air-conditioned rooms. This study did not take into account the effect of time dependency; therefore the actual thermal performance of the building may differ. Nevertheless, the difference is unlikely to affect the conclusions as the results of this study represent the worst case scenario.

Table 6. Heating requirements and energy savings for different building configurations.

\begin{tabular}{llll}
\hline Building Configuration & $\begin{array}{l}\text { Heating requirements } \\
\text { (kWh/yr) }\end{array}$ & $\begin{array}{l}\text { Savings over the life } \\
\text { span of the building } \\
\text { compared to economic } \\
\text { house (GJ) }\end{array}$ & $\begin{array}{l}\text { Savings over the life } \\
\text { span of the building } \\
\text { assuming 90\% } \\
\text { efficiency (kg-LPG) }\end{array}$ \\
\hline Economic & 4204 & - & - \\
Improved Economic & 3150 & 189.72 & 4572 \\
Insulated Economic & 2011 & 394.70 & 9513 \\
Typical Limestone & 3498 & 127.00 & 3061 \\
Insulated limestone & 2084 & 381.60 & 9198 \\
Luxury & 1849 & 423.90 & 10217 \\
\hline
\end{tabular}

Table 7. LCIA results for typical Jordanian HVAC levels

\begin{tabular}{|c|c|c|c|c|c|c|c|}
\hline Impact Category & Units & $\begin{array}{l}\text { Economic } \\
\text { House }\end{array}$ & $\begin{array}{l}\text { Improved } \\
\text { Economic }\end{array}$ & $\begin{array}{l}\text { Insulated } \\
\text { Economic } \\
\text { House }\end{array}$ & $\begin{array}{l}\text { Typical } \\
\text { Limestone }\end{array}$ & $\begin{array}{l}\text { Insulated } \\
\text { Limestone }\end{array}$ & $\begin{array}{l}\text { Luxury } \\
\text { House }\end{array}$ \\
\hline Climate Change & $\begin{array}{l}\mathrm{Mg} \\
\mathrm{CO} 2 \mathrm{eq}\end{array}$ & 727.85 & 821.85 & 807.35 & 800.31 & 817.2 & 934.97 \\
\hline Human toxicity & $\begin{array}{l}\text { kg 1,4- } \\
\text { DB eq }\end{array}$ & 24.48 & 26.56 & 26.56 & 18.17 & 18.19 & 20.26 \\
\hline $\begin{array}{l}\text { Particulate } \\
\text { matter } \\
\text { formation }\end{array}$ & $\begin{array}{l}\text { Mg } \\
\text { PM10 } \\
\text { eq }\end{array}$ & 1.14 & 1.31 & 1.31 & 1.27 & 1.33 & 1.53 \\
\hline $\begin{array}{l}\text { Terrestrial } \\
\text { acidification }\end{array}$ & $\begin{array}{l}\mathrm{Mg} \\
\mathrm{SO} 2 \mathrm{eq}\end{array}$ & 2.91 & 3.37 & 3.36 & 3.26 & 3.40 & 3.92 \\
\hline Water depletion & m3 & 60.86 & 67.77 & 69.48 & 49.45 & 51.8 & 59.05 \\
\hline $\begin{array}{l}\text { Total-Energy } \\
\text { Resource }\end{array}$ & UBP & 5049.95 & 5851.78 & 5853.04 & 5700.86 & 5988.41 & 6887.2 \\
\hline
\end{tabular}


Cite this article as: El Hanandeh, A. (2015). Environmental assessment of popular single-family house construction alternatives in Jordan. Building and Environment, 92, pp192-199.

Worthy to note is that limestone based houses, generally show lower impacts in human toxicity and water depletion categories. This is mainly due to the lower processing and manufacturing required to produce the cut stones compared to concrete blocks. Contrary to the commonly held belief of many, the use of limestone in the exterior wall, although a natural material, did not improve the overall environmental performance of the building. This is mainly because in the current construction practice, thin limestone tiles (usually $30 \mathrm{~mm}$ thick) are used as part of the cladding which offers little insulation or structural functionality but requires other more energy and resource intensive material (usually concrete) to be used as backing to hold it in place. The finding of this study is in agreement with loannidou et al [31] who also concluded after conducting an LCA study of stone wall systems in Switzerland that the use of thin stone cladding does not necessarily offer the most sustainable option. This also brings into question the rationale behind the policy adopted by many municipalities in Jordan which requires buildings in commercial zones to have stone cladding facing the road for aesthetic purposes. Should environmental considerations be also taken into account in the policy rather than relying on aesthetics alone?

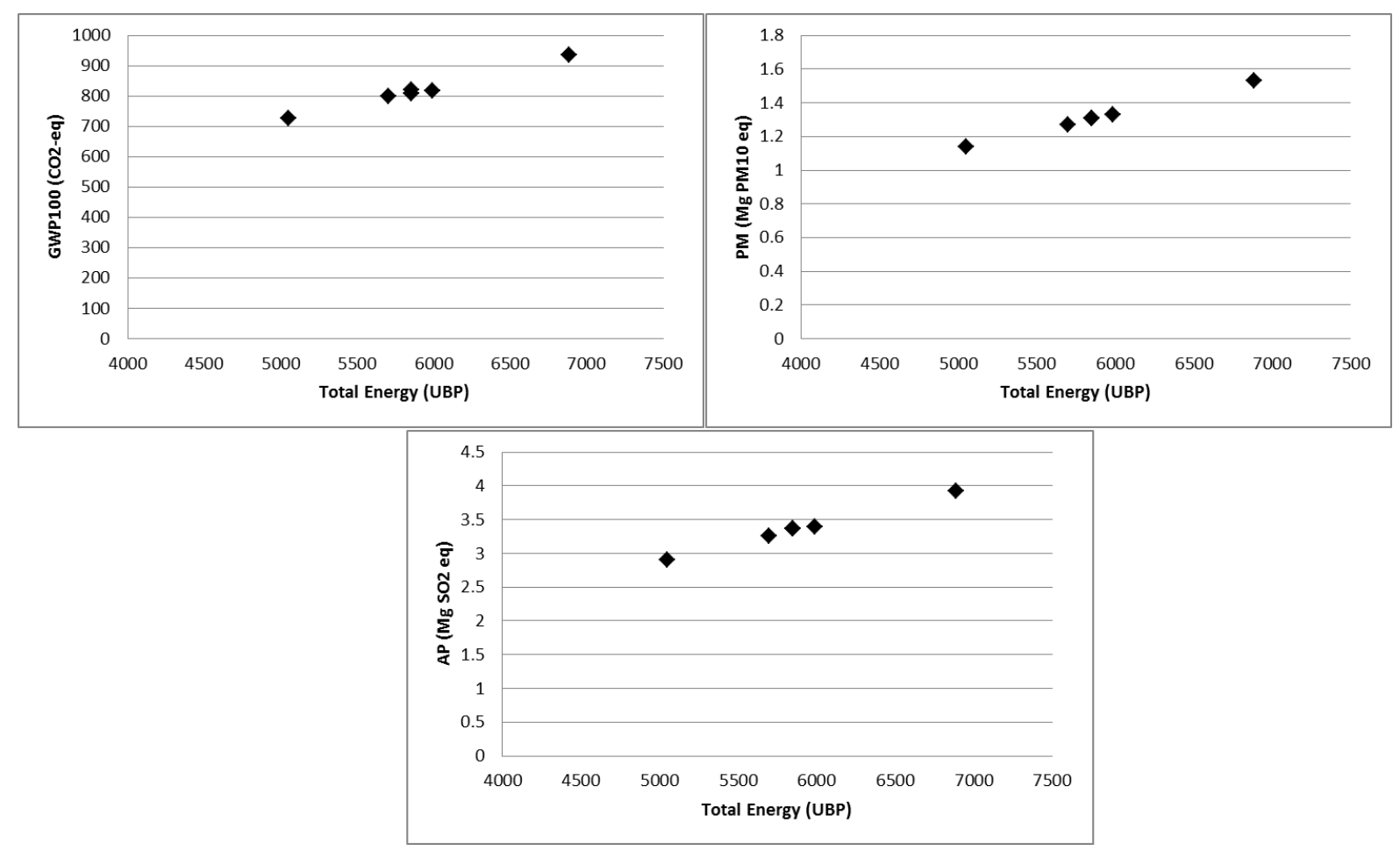

Figure 4. Relationship between GWP100, PM, AP impacts and Total Energy 
Cite this article as: El Hanandeh, A. (2015). Environmental assessment of popular single-family house construction alternatives in Jordan. Building and Environment, 92, pp192-199.

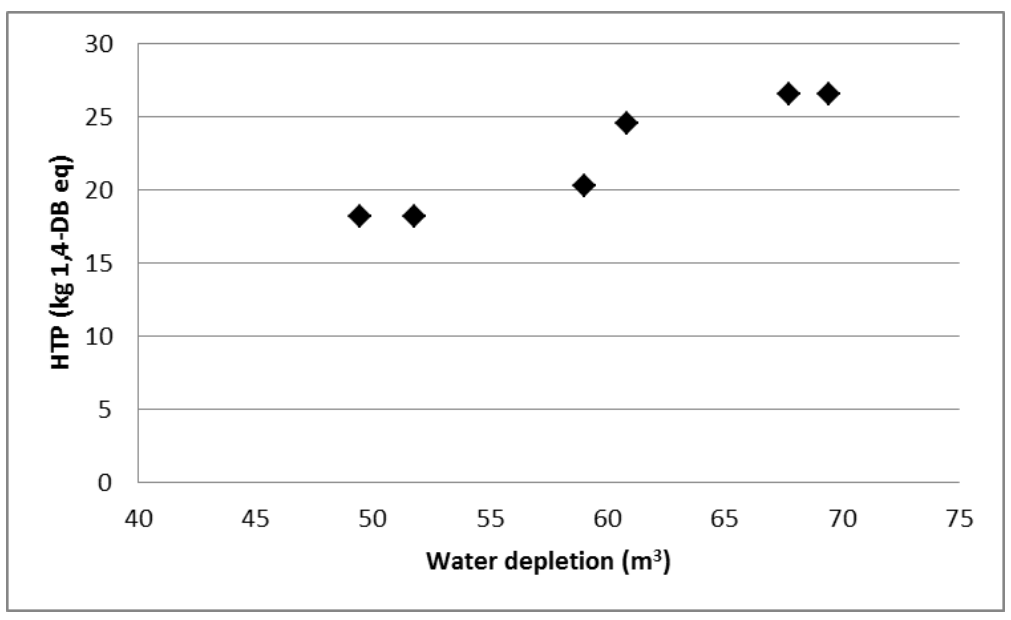

Figure 5. Relationship between HTP and water depletion potential

As evident from Figure 4, there is strong correlation between energy resource, climate change, particulate matter formation and terrestrial acidification impacts $(r=0.993,0.998,0.999$, respectively) suggesting that Total-Energy Resource impact can be used as a proxy indicator of the system. Nevertheless, weak negative correlation ( $r=-0.32$ ) exists between energy resource impact and human toxicity impact. Furthermore, a very weak correlation $(r=-0.05)$ is noticed between energy resource and water resource depletion impacts. On the other hand, Figure 5 shows that a strong positive correlation ( $r=0.957)$ exists between water depletion and human toxicity which suggests that human toxicity impacts of the system are mainly due to emissions to water. Based on the results, water depletion and energy resource impacts can be used as proxy indicators of the overall performance of single-family house building in Jordan. Coincidently, water and energy resources are the most pressing issues in Jordan and therefore are good proxy measures to monitor.

\section{Sensitivity Analysis}

The overall performance of the building is sensitive to energy use during the operational phase. The use of multi-layered wall configuration in Jordan is often promoted on the basis of energy efficiency during the operation phase. In most cases these recommendations are based on findings from colder climates and different HVAC patterns than those usually adopted by typical Jordanian families. To test the effect of different heating patterns on the overall results, a scenario where the entire house heating and cooling is maintained the preferred temperatures $\left(20^{\circ} \mathrm{C}\right.$ and $25^{\circ} \mathrm{C}$, respectively) for periods of time as described earlier (three hours during day time and six hours during the night) is tested.

The intermittent use of heating and cooling results in comparatively low energy demand compared to European families. When the entire house climate control is assumed, the energy demand, during the operation phase of the building, increases dramatically as shown in Table 8.

Table 8. HVAC requirements for heating and cooling the entire house to a constant temperature $\left(20^{\circ} \mathrm{C}\right.$ in winter, $25^{\circ} \mathrm{C}$ in summer)

\begin{tabular}{l|lll} 
House Type & Heating $(\mathrm{kWh} / \mathrm{yr})$ & Cooling $(\mathrm{kWh} / \mathrm{yr})$ & Total $(\mathrm{kWh} / \mathrm{yr})$ \\
\hline Economic & 16,972 & 4,223 & 21,196
\end{tabular}


Cite this article as: El Hanandeh, A. (2015). Environmental assessment of popular single-family house construction alternatives in Jordan. Building and Environment, 92, pp192-199.

doi:10.1016/j.buildenv.2015.04.032

Improved Economic Insulated Economic

Typical Limestone Insulated Limestone Luxury

$\begin{array}{ll}14,794 & 3,663 \\ 13,313 & 3,282 \\ 15,513 & 3,848 \\ 11,029 & 2,703 \\ 10,289 & 2,513\end{array}$

14,794

13,313

10,289
3,663

3,282

2,703

2,513
18,457

16,594

19,360

13,733

12,802

As expected, higher HVAC requirements result in higher overall environmental impacts. Elaborate wall configurations show better performance in human toxicity than the economic house when higher HVAC requirements are assumed. On the other hand, despite the high reduction in energy requirement during the operation phase, more elaborate configurations fare less favourably in other impact categories compared to the economic house from a life cycle perspective. For example, the luxury house configuration is ranked last in the Energy Resource impact category (7117.9 UBP) while the economic house continues to be the best performer from life cycle perspective (5433.7 UBP).

Another factor that may influence the environmental performance of a building is the end of life treatment. Currently, landfilling is the prevailing end of life treatment for demolition waste. Due to the difficulty of extracting rebars and other recyclables from the rubble, these materials are usually not recovered. However, if rebars were recovered and recycled as scrap metal then some environmental benefits may be realised due to the reduced energy demand of recycled steel. Nevertheless, Jordanian steel reinforcement bars are manufactured from recycled material and therefore, the benefits of recycling may be negligible. On the other hand, limestone tiles are easier to extract and may be recycled as paving tiles or crushed aggregate stone. Recycling limestone tiles into aggregate will require around $35.4 \mathrm{MJ} / \mathrm{Mg}$. However, it will save $817 \mathrm{MJ} / \mathrm{Mg}$ due to offset energy from extraction of limestone. Using the Jordanian electricity grid mix and assuming a recycling rate of $50 \%$, a total energy saving of up to $12.94 \mathrm{GJ}$ per house translates to total greenhouse gas emission savings of $11 \mathrm{Mg} \mathrm{CO} 2 \mathrm{eq}$. Still, the savings are not sufficient to alter the ranking of the alternatives. These results may indicate that under the prevailing conditions and due to the low energy demand of the Jordanian houses, energy efficient houses may only provide marginal benefits if houses are operated as passive buildings.

\section{Conclusions}

This study analysed the six most common single-family house construction configurations in Jordan using life cycle methodology. Results showed that under the low energy requirements for HVAC, the economic house with walls constructed from a single layer of hollow concrete blocks offers the best environmental performance from a life cycle perspective. Even though more elaborate wall construction with insulation reduces energy use during the operation phase, it has higher environmental impacts over the life span of the buildings when material production, construction, demolition and disposal phases are considered. Contrary to the commonly held belief, limestone cladding did not necessarily offer better environmental performance. Among the six environmental impact categories relevant in the Jordanian context, water depletion and energy resource impacts are found to be the most significant with all other impacts highly correlated to them. Therefore, it is suggested that water depletion and energy resource impacts be used as proxy indicators of the overall environmental performance of the single-family house in Jordan. 
Cite this article as: El Hanandeh, A. (2015). Environmental assessment of popular single-family house construction alternatives in Jordan. Building and Environment, 92, pp192-199.

doi:10.1016/j.buildenv.2015.04.032

Acknowledgment

The author would like to thank Ms Pauline Fraser, Library and Learning Services, Griffith University for proof reading the manuscript and for her valuable comments and suggestions.

References

[1] JIB. $(2015,18 / 02 / 2015)$. Available: http://www.jib.jo/IndustrySectors/ConstructionBuildingMaterials/tabid/99/language/enUS/Default.aspx

[2] A. Horvath, "Construction materials and the environment," Annu. Rev. Environ. Resour., vol. 29, pp. 181-204, 2004.

[3] WHO. (2015, 18/02/2015). Available: http://www.who.int/heli/pilots/jordan/en/

[4] H. Monteiro and F. Freire, "Life-cycle assessment of a house with alternative exterior walls: Comparison of three impact assessment methods," Energy and Buildings, vol. 47, pp. 572583, 2012.

[5] K. Adalberth, "Energy use during the life cycle of buildings: a method," Building and Environment, vol. 32, pp. 317-320, 1997.

[6] I. Sartori and A. Hestness, " Energy use in the life cycle of conventional and lowenergy buildings: a review article," Energy and Buildings, vol. 40, pp. 249-57, 2007.

[7] H. Radhi and S. Sharples, "Global warming implications of facade parameters: A life cycle assessment of residential buildings in Bahrain," Environmental Impact Assessment Review, vol. 38, pp. 99-108, 1// 2013.

[8] M. Maria Kolokotroni, S. Robinson-Gayle, S. Tanno, and A. Cripps, "Environmental impact analysis for typical office facades," Building Research \& Information, vol. 32, pp. 2-16, 2004.

[9] E. Johansson and D. Ouahrani, Eds., Climate Conscious Architecture and Urban Design in Jordan-Towards energy efficient buildings and improved urban microclimate (Report 12. Sweden: Lund: Housing Development \& Management and the Royal Scientific Society, 2009, p.^pp. Pages.

[10] D. Ouahrani, "Towards energy efficient buildings in Amman, Jordan: Defining thermal requirements by mean of thermal simulations," presented at the 44th Annual Conference of the Architectural Science Association, ANZAScA 2010, Unitec Institute of Technology, 2010.

[11] H. H. Ali and S. F. Al Nsairat, "Developing a green building assessment tool for developing countries - Case of Jordan," Building and Environment vol. 44, pp. 1053-1064, 2009.

[12] DOS. $(2013,24 / 02 / 2015)$. Estimated Population by Governorate, Sex and Pop. Density (P/Km2), 2013. Available: http://www.dos.gov.jo/dos home a/jorfig/2013/3 1.pdf

[13] DOS. (2004, 22/02/2015). Population and housing censues. Available: http://www.dos.gov.jo/dos home e/main/index.htm

[14] ISO, "ISO 14040. Environmental managementeLifecycle assessmentePrinciplesandframework," ed. Geneva.: International Standardization Organization, 2006.

[15] "openLCA," 1.4 ed. www.greendelta.com: GreenDelta, 2014.

[16] R. M. Cuéllar-Franca and A. Azapagic, "Environmental impacts of the UK residential sector: Life cycle assessment of houses," Building and Environment, vol. 54, pp. 86-99, 2012.

[17] University of Tenesse Center for Clean Products, "Limestone Quarrying and Processing: A Life-Cycle Inventory," Natural Stone Council, Knoxville, TN 37996-41342008.

[18] M. Marceau, M. A. Nisbet, and M. G. Van Geem, "Life cycle inventory of portland cement manufacture," Portland Cement Association, Skokie, IL2006. 
Cite this article as: El Hanandeh, A. (2015). Environmental assessment of popular single-family house construction alternatives in Jordan. Building and Environment, 92, pp192-199.

[19] Joint Research Centre, "ELCD," ed. http://eplca.jrc.ec.europa.eu/: European Commission, 2013.

[20] D. o. S. J. a. I. Macro, "Jordan Population and Family Health Survey 2009," Department of Statistics and ICF Macro, Calverton, Maryland, USA2010.

[21] E. D. Weather. (2015, 10/02/2015). Irbid Jordan Yearly Climate Temperature and Precipitation. Available: http://www.eldoradocountyweather.com/climate/iordan/Irbid.html

[22] I. Etier, A. Al Tarabsheh, and M. Ababneh, "Analysis of Solar Radiation in Jordan," Jordan Journal of Mechanical and Industrial Engineering vol. 4, pp. 733 - 7382010.

[23] A. A. Rousan and A. Shariah, "Solar and Thermal Energy Gain Through Windows in Jordan," Renewable Energy, vol. 7, pp. 251-269, 1996.

[24] ReCiPe. (2013). ReCiPe. Available: http://www.lcia-recipe.net/

[25] R. Frischknecht, R. Steiner, and N. Jungbluth, The Ecological Scarcity Method-Eco-Factors 2006. A method for impact assessment in LCA. Bern: Federal Office for the Environment, 2009.

[26] Government of Jordan, "Water for Life-Jordan's water strategy 2008-2022," Royal Commission for Water, Amman2009.

[27] Ministry of Environment, "The National Climate Change Policy of the Hashemite Kingdom of Jordan 2013-2020 - Sector Strategic Guidance Framework," Ministry of Environment (Jordan)2013.

[28] A. El Hanandeh, "The environmental performance of future power generation scenarios in Jordan," presented at the 7th Jordan International Chemical Engineering (JICHE07) Conference, Amman, Jordan, 2014.

[29] G. Barrios, G. Huelsz, R. Rechtman, and J. Rojas, "Wall/roof thermal performance differences between air-conditioned and non air-conditioned rooms," Energy and Buildings, vol. 43, pp. 219-223, 2011.

[30] G. Barrios, G. Huelsz, and J. Rojas, "Thermal performance of envelope wall/roofs of intermittent air-conditioned rooms," Applied Thermal Engineering, vol. 40, pp. 1-7, 2012.

[31] D. Ioannidou, S. Zerbi, and G. Habert, "When more is better-Comparative LCA of wall systems with stone," Building and Environment, vol. 82, pp. 628-639, 2014. 